Vol. I No. 3 - December 2020

\title{
The Influence of Government Subsidy and Pro-environmental Gaps on Electricity-saving Behaviors of Households in Indonesia
}

\author{
Dimas Abi Aufan \\ Master of Economic Planning and Development Policy, Faculty \\ of Economics and Business University of Indonesia, Depok, \\ Indonesia \\ dimas.mpkp@gmail.com
}

\begin{abstract}
This research analyzes whether electricity subsidy as an external factor and pro-environmental intention and acts as internal factors have any relationship on households' electricity-saving behaviors in Indonesia. To this end, Indonesia's household data from the National Socioeconomic Survey of Indonesia (SUSENAS) in 2017 is empirically analyzed. Using logit regression with control factors such as dwellings and sociodemographic characteristics, the statistical analysis reveals that subsidized households are less likely to save electricity in their daily lives. Furthermore, families with higher pro-environmental intentions are not necessarily likely to save electricity, while households who are accustomed to pro-environmental routines are likely to do so. These demonstrate the existence of internal gaps between their proenvironmental intention and the acts, suggesting that electricity subsidies reform and program should be considered along with the way how intention-act gaps can be mitigated at household levels for energy saving.
\end{abstract}

Keywords: electricity-saving behaviors, pro-environmental, subsidies.

ARTICLE INFO

Received: Dec 16, 2020

Received in revised form: Dec 18, 2020

Accepted: Dec 27, 2020
JISDeP - The Journal of Indonesia Sustainable Development Planning Published by Centre for Planners'

Development, Education, and Training (Pusbindiklatren),

Ministry of National Development

Planning/ National Development

Planning Agency (Bappenas), Republic of Indonesia
Address: Jalan Proklamasi 70,

Central Jakarta, Indonesia 10320

Phone: +62 $2131928280 / 3192828$

Fax: +62 2131928281

E-mail: pusbindiklatren@bappenas.go.id

Supported by Indonesian Development Planners Association (PPPI) 


\section{Introduction}

Inefficient use of electricity and over-dependence on non-renewable electricity sources such as coal are the reasons why climate change and limited stock of non-renewable resources become crucial issues. These issues are closely related to Sustainable Development Goals (SDGs) especially goal no. 7: affordable and clean energy, and goal no. 13: climate action. Along with an increase in population and economic growth, the electricity demand also increases. Figure 1 depicts average annual growth in percapita electricity consumption in South East Asia in which Indonesia's per-capita electricity consumption is almost similar to the average of overall ASEAN's.

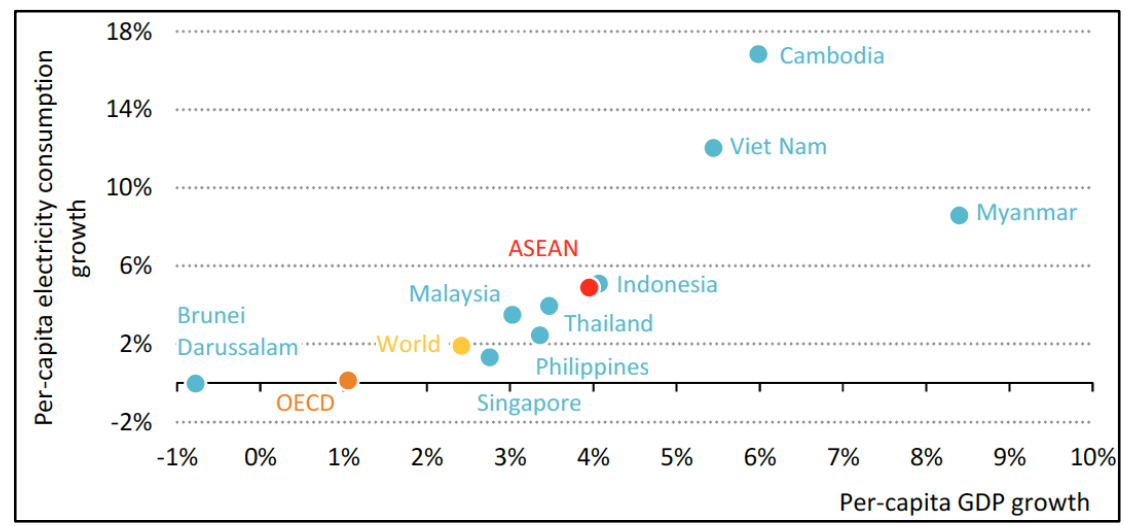

Figure 1. Average annual growth in per-capita electricity consumption in South East Asia, 20002015 (IEA, 2017)

In Indonesia's context, the need for an additional power plant with 4.1 gigawatts (GW) of capacity per year until 2030 is projected, in which $50 \%$ of the capacity is produced by the coal power plant (International Energy Agency, 2017). This projection indicates that consumption will still rise with the increase in population. Also, the household sector stands in the first position as the final energy consumer in Indonesia, with $42.33 \%$ comes from electricity consumption as can be seen in figure 2 (Ministry of Energy and Mineral Resources Republic of Indonesia, 2018). In terms of electricity consumption per capita, Indonesia is relatively low at approximately 1,048 kWh/capita in 2018 or equal to a quarter of the world average (International Energy Agency, 2017). Besides, Indonesia's electricity is predominantly fossil-fuel-based, with $50 \%$ from coal, $29 \%$ from natural gas and $7 \%$ come from oil. Accumulation of renewable sources such as hydro, geothermal, and so on shared $14 \%$, as shown in figure 3 . Coal-based power plants, which are the majority in Indonesia, are one of the largest contributors to $\mathrm{CO}_{2}$ emissions. Institute for Essential Services Reform (IESR) states that Indonesia experiences significant growth of $\mathrm{CO}_{2}$ emissions for approximately 18\% throughout 2012-2017 (IESR, 2019). This becomes a challenge for Indonesia in achieving SDGs.

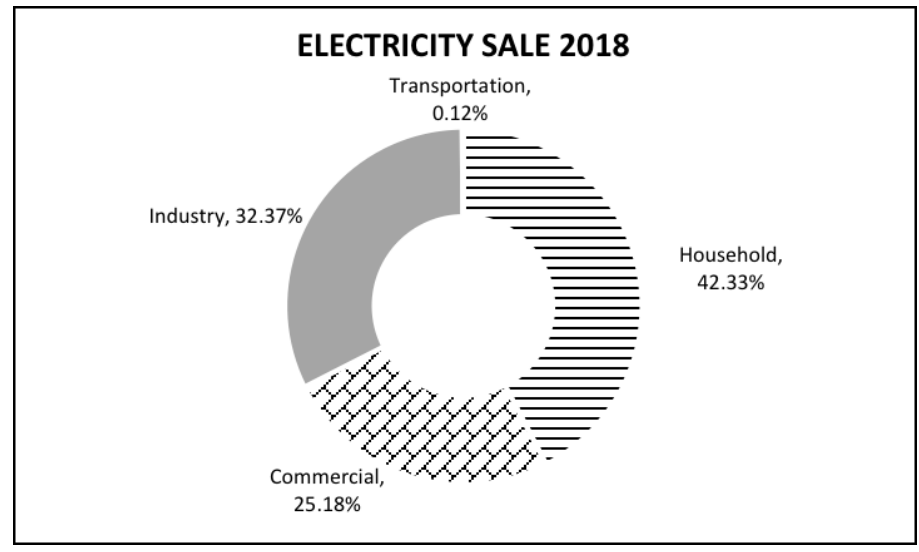

Figure 2. Electricity Sale 2018 (HEESI, 2018) 


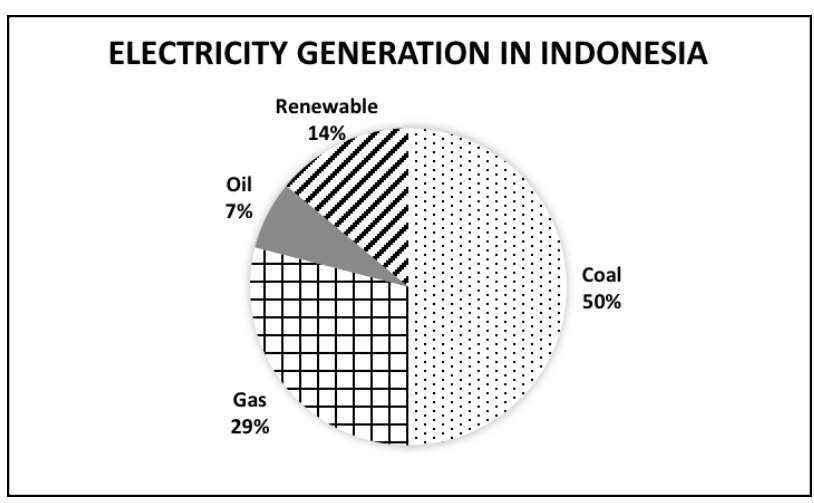

Figure 3. Electricity Generation in Indonesia 2018 (HEESI, 2018)

The government set the electricity prices and delegate Perusahaan Listrik Negara (PLN) as a government-owned corporation to distribute electricity throughout Indonesia. For the households sector, the costs are divided into several consumer groups based on the capacity installed in their house. Especially for residences with connections of 450 VA and 900 VA, they will face an increasing block tariff structure. The electricity tariff subsidies for households are given by setting the price below the cost of supplying electricity. The difference will be covered by tax and will be given to PLN. Assisting the poor, increasing industrial competitiveness, and stabilizing prices become the main objectives of the subsidies (Burke \& Kurniawati, 2018). However, this policy brings a heavy burden on the financial side of the government. In 2012, the annual electricity subsidies boomed to approximately 103.3 trillion IDR, as shown in figure 4. Moreover, the biggest problem of these electricity subsidies is in the distribution, which is not on the right target. From 2015 to 2017, for instance, the government gives subsidies to households with an electricity capacity installed of 450 VA and 900 VA without considering their level of income. As a result, many non-poor homes receive subsidies. PLN states that in 2016, 18.7 million out of 22.7 million consumers with connections of 900 VA come from wealthy families.

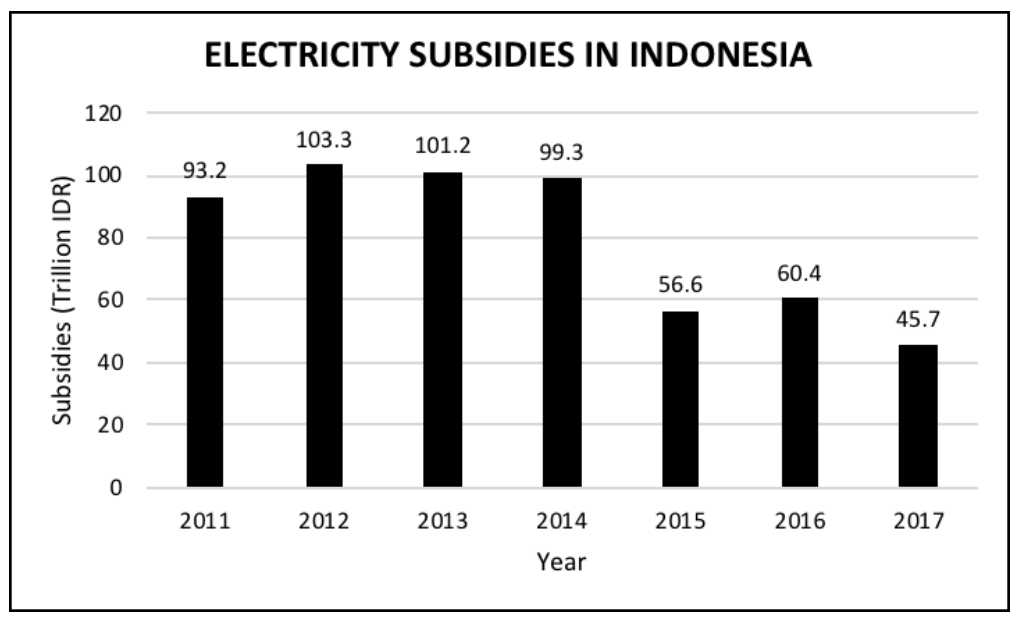

Figure 4. Electricity subsidies in Indonesia (PLN Statistics)

Along with the subsidies reform policies, the government also promotes a campaign called "cut $10 \%$ " to encourage people to cut their electricity consumption by $10 \%$ by implementing electricity-saving behaviors such as turning off lights when unused and using a timer when using air-con. $10 \%$ is reasonable since this percentage is the amount that can be saved without having to spend more investment like purchasing energy-saving appliances. The government simulates that the savings of $10 \%$ for the next three years are equal to the development of a new electric steam power plant. Additionally, it can also electrify about 2.5 million families in all villages in 6 provinces in Eastern Indonesia, which is equivalent to 10 million people. This campaign is expected to make people aware that not only financial benefits will be obtained, but also a positive impact on the environment. It contributes to reducing $\mathrm{CO}_{2}$ emission resulting from fossil-fuel based power plant (SDGs no. 7 and 13).

Consequently, the implementation of energy efficiency and energy saving, especially in terms of electricity consumption in households, are essential to face the SDGs issues since resident behaviors play an indispensable role. Households can lower their energy consumption by adopting energy-saving 
behaviors. Energy-saving is more about a change in consumer behaviors that leads to energy savings without investing in new technologies (Oikonomou, Becchis, Steg, and Russolillo, 2009). Studies show that energy-saving routines are affected by internal factors such as environmental concern, and external factors such as government policies.

In Indonesia, the government gives electricity subsidies to particular households. It means that a subsidized household experiences lower price and have a disincentive to save electricity. Furthermore, there is also a gap between their environmental consciousness and environmental acts that can also affect the behaviors. Nusrat Afroz \& Zul Ilham (2020), for instance, perform a study to investigate the awareness level of University of Malaya students towards SDGs and find that there is a negative correlation between student's knowledge and practice level. Jamaludin et al. (2020) show that there is also a gap in interpretation that indicates the need for more intellectual activities that covers information on the development, technologies, and benefit of renewable energy. Therefore, it is crucial to understand the right policy and factors that can influence the responses of the household. Then, hypotheses could be taken that government subsidies policy lower electricity-saving habits and pro-environmental gap also matter.

This research tries to complete the previous study by using 187.000 household data from the National Socioeconomic Survey of Indonesia 2017. Furthermore, most of the studies have a similar objective, which is to examine the determinants that influence energy-saving behaviors in general. Therefore, to fill the gap between previous studies, this study only focuses on the impact of electricity subsidies and the pro-environmental gap on the behaviors of the household. The other variables or factors such as socio-demographic and dwelling characteristics will be treated as control variables. Moreover, this study only concentrates on daily electricity-saving behavior, not on the transformation to renewable energy. This paper will utilize logistic regression (LOGIT) to analyze the relationships among variables which will be explained in more detail in the methodology section.

\section{Literature Review}

Previous studies examine the relationship of sociodemographic characteristics on energy-saving behaviors. A study conducted by Schleich, Mills, and Dütschke (2014) in Germany shows that younger people tend to save energy more for environmental reasons while older people tend to do so for financial reasons. Yang, Zhang, and Zhao (2016), who researched Hefei, China, found that the energy-saving level of married people is significantly higher than that of unmarried people. Besides, women's daily energysaving behaviors level and their intention to invest in energy efficiency are considerably higher than those of males. Trotta (2018), using British household data, also shows that low-income households tend to implement energy-saving behaviors more through daily activities compared to the medium and highincome, while the level of education is not a significant factor that influences energy-saving actions. It contradicts Yue, Long, and Chen (2013) which find that educational background is an essential factor affecting energy-saving behaviors in Jiangsu Province, China. In general, studies show that sociodemographic aspects have a significant association with energy-saving practices.

Some researchers take into account environmental aspects to investigate their significance in terms of energy-saving behaviors. Hori, Kondo, Nogata, and Ben (2013), in their comparison of five major cities in Asia, shows that global warming consciousness, environmental behaviors, and social interaction significantly influence energy-saving practices. Sardianou (2007) estimates determinants influencing energy-saving behaviors in Greece and founds those energy-saver consumers have keen environmental consciousness of energy problems. Another study by Ding, Wang, Liu, and Long (2017) in Jiangsu, China, reveals that a sense of responsibility for the environment becomes the main factor that supports daily energy-saving. However, Ohler and Billger (2014), who compare the influence of self and social interest on electricity consumption, show different findings where self-interests have a higher impact on energysaving behaviors and electricity use regardless of an individual's environmental concern.

Dwelling factors have to be taken into account since there is a lot of research that wants to measure their significance in terms of energy-saving behavior. These features include the kind of homeownership, size of the house, number of rooms, the source of lighting, the capacity of electricity installed, and electrical appliances owned by households. J. Walsh (1989) through his survey, found that conservation engagements are less likely to be implemented by those who rent a house since their expectations are relatively low due to a shorter contract in their dwellings. Another significant result that is obtained by Barr et al. (2005) showed that based on a database of 1265 household in Devon, those who own the house tend to have more awareness in terms of energy-saving behavior compared to the renters. 
More recently, Trotta (2018) explained that the type of house that a household lives in becomes a significant determinant of energy-saving measures and the investment in energy-efficient retrofits. Those who live in a flat seem to be more possible to implement energy-saving behavior through daily activities. Moreover, previous studies also show that home specification matters in influencing energy-saving behavior. Households who live in large dwellings, as approached by the number of rooms and floors, consume more energy than those who live in a smaller house (Ritchie, Mcdougall, Claxton, Mcdougall, \& Claxton, 1981). Walsh (1989) supported this argument and found that the older and larger the dwelling is, a household has a higher probability to implement energy conservation actions. Uidhir, Rogan, Collins, Curtis, \& Gallachóir (2020) show that alternative retrofit choices have a positive impact on energy efficiency.

External factors such as government policy also become one of the variables of interest. Hong, She, Wang, and Dora (2019) observe the impact of subsidies incentive policy for energy-saving products on the energy-saving behaviors of residents in China and shows that the policy has a positive effect on the actions. Zhao, Cheng, Zhao, Jiang, and Xue (2019) finds that the price of energy-saving products is a matter for farmers. Still, in China, Liu and Lin (2020) reveal that the implementation of increasing-block electricity pricing encourages household electricity-saving at a particular level. Nakano et al. (2018) try to explore factors influencing willingness to purchase LED lighting in Indonesia. They expose that information about the national energy efficiency labeling program shows a positive impact on the purchasing decision. This research describes that government intervention could influence the behaviors of households.

Even though a lot of studies have been done, the findings are varied. This diversity probably happens because of the different characteristics between locations, and sample-sized used might not be enough to represent the region. Some researchers explicitly state that they have limitations in terms of sample size that are too small and not enough to describe the region, and they realize that a larger sample size will give better results (S. Wang et al., 2018; Ru, Wang, \& Yan, 2018; Zhang, Yu, Wang, \& Wei, 2018; Erell, Portnov, \& Assif, 2018; Mizobuchi \& Takeuchi, 2013). Moreover, many studies use primary data from hundreds number of respondents (Ohler \& Billger, 2014; Vogiatzi et al., 2018; Sardianou, 2007; Webb, Soutar, Mazzarol, \& Saldaris, 2013; Z. Wang, Zhang, Yin, \& Zhang, 2011; S. Wang, Lin, \& Li, 2018).

\section{Data and Methodology}

To investigate the impact of electricity subsidies and the environmental gap on the electricitysaving behaviors of households, this study employs binary logistic regression (LOGIT). The following basic specification is used:

$$
\operatorname{Logit}(R)=\frac{1}{1+e^{-z}} ; z=\beta_{0}+\sum_{i=1}^{n} \beta_{1} \text { subsidy }_{i}+\beta_{2} \text { env gap } \operatorname{gap}_{i}+\beta_{3} x_{i}^{\prime}+\varepsilon_{i}
$$

Where $z$ is latent measures of household commitment in electricity-saving, $\beta$ is the vector of parameters to be estimated, $\operatorname{subsid}_{i}$ is a dummy variable for subsidized household, env gap $p_{i}$ is variable of household's environmental gap, $x_{i}^{\prime}$ refers to sociodemographic and dwelling characteristics, which are introduced as control variables for household $i$ and $\varepsilon$ is the error term. Then, the marginal effect of a change in the explanatory variable on the expected value of the dependent variable is calculated. The marginal effect will be interpreted as a percentage, not as a percentage point.

Logit regression is employed since the dependent variable is the binary type, where "1" equals $100 \%$ implement electricity-saving behaviors, and "0" equals not $100 \%$ implement electricity-saving behaviors. Besides, logit is relevant to be utilized in maximizing utility case. Wang et al. (2011) explain that people's commitment to electricity-saving principally depends on the expected utility from their saving habit. Previous studies such as Fiorillo \& Sapio (2019), Wang et al. (2011), Nakano et al. (2018), and Umit, Poortinga, Jokinen, and Pohjolainen (2019) also employ logistic regression to observe energy-saving behaviors. Hopefully, this method could answer the research question well

This study utilizes the data from the National Socioeconomic Survey of Indonesia (SUSENAS) year of 2017. SUSANA'S is a regular survey conducted by the Central Bureau of the Statistics Republic of Indonesia (BPS) to obtain information related to socio-economic aspects. In detail, this survey captures data and information in various areas such as education, criminality, employment, health, family planning, housing, environment, household consumption, etc. SUSANA'S 2017 dataset is matched with the needs of this study since it contains specific information related to the behaviors of households in consuming energy. This kind of information does not exist in other SUSENAS survey. Furthermore, the data consists of 187,790 households who have electricity connections in their homes. By considering that an increase 
in population is accompanied by an increase in electricity consumption, the 2017 data is quite relevant to current conditions.

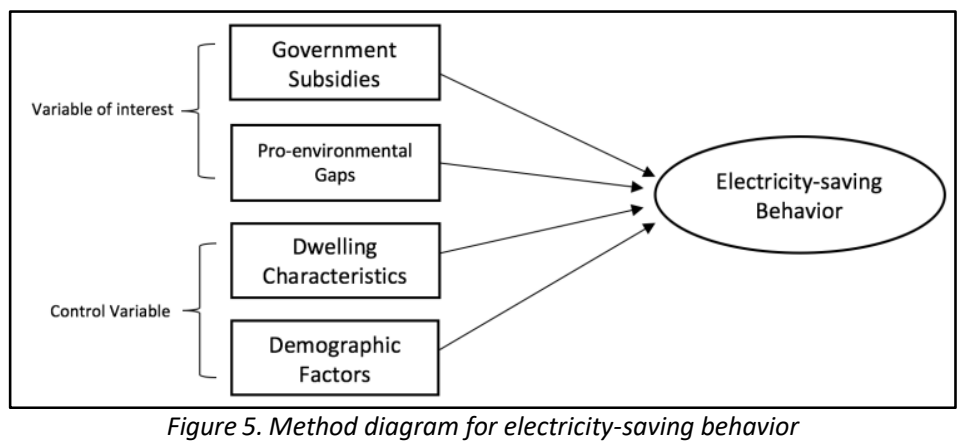

The overview of the methodology of this study can be seen in figure 5 . This study will focus on habitual energy-saving behaviors, specifically, the electricity-saving habit of a household since one of the approaches of energy-saving actions is habitual energy-saving behaviors (B. Wang, Wang, Guo, Zhang, \& Wang, 2018). Besides, habitual energy-saving is more easily adopted since such activity requires a little cost. To represent a household's electricity-saving behaviors as a dependent variable, this study selects information from SUSENAS whether or not a family turns off electrical appliances when unused. This type of action is also used in previous studies such as Zhang et al. (2018), Hori et al., (2013), Yue et al. (2013), and Sardianou (2007).

Financial factors have an essential role in determining consumer behaviors. Hence, this study takes into account electricity subsidies as the variable of interest as shown in figure 5 . Electricity subsidies are expected to affect the electricity-saving behaviors of households due to differences in electricity rates. In this study, subsidized families are categorized based on the requirement from the government, namely those who have 450 VA and 900 VA of electricity capacity installed. From the result of the grouping, it appears that $79 \%$ of households receive electricity subsidies.

Another variable of interest in this study is the household's pro-environmental gap. There is frequently a sizeable inconsistency between people's intentions and observable behaviors in the environmental aspect. Sheeran and Webb (2016) explain this inconsistency as the intention-behavior gap. In the environmental context, some people have good pro-environmental intentions but do not implement them as a real habit or vice versa. To measure the environmental intentions and acts, household heads were being asked for their opinion about some environmental statements and behaviors followed by a Likert-type scale of $1-4$, as shown in table 1 and table 2 . Then, the environmental gap is calculated by subtracting the total value of the intentions and acts. As the gap increases, the level of proenvironmental intention is higher but not accompanied by the rise in pro-environmental behaviors.

Table 1: Pro-environmental intentions.

\begin{tabular}{ll}
\hline No & Statements* \\
\hline 1 & Households need to provide water absorption areas \\
2 & Not burning garbage can reduce air pollution \\
3 & Households need to do waste separation before disposed \\
4 & Households need to bring their shopping bag when shopping \\
5 & Prefer to use mass transport compared to private vehicle \\
6 & Motor vehicle engines need to be regularly maintained \\
7 & Households need to grow plants at home \\
8 & Households need to participate in environmental community service in the neighborhood \\
\hline$*$ ) 1=Disagree, 2=Partially Agree, 3=Agree, 4=Totally Agree
\end{tabular}

Table 2: Pro-environmental Acts

\begin{tabular}{ll}
\hline No & Questions* \\
\hline 1 & Does the household provide water absorption areas? \\
2 & Does the household not burn trash? \\
3 & Does the household do waste sorting before disposed of? \\
4 & Does the household bring their shopping bag when shopping? \\
5 & Does the household prefer to use mass transport compared to the private vehicle? \\
6 & Does the household regularly maintain motor vehicle engines? \\
7 & Does the household grow plants at home? \\
\hline
\end{tabular}


8 Does the household participate in environmental community service in the neighborhood?

*) 1=Never, 2=Sometimes, 3=Often, 4=Always

Furthermore, sociodemographic characteristics and dwelling features are included in the estimation as control variables as shown in figure 5 . In detail, table 3 shows the variables included in the model and the summary statistics. The household sizes range from 1 to 22 , with an average of one family having four members. They all live in urban and rural areas with a ratio of almost 50:50. Approximately $81 \%$ of them own their house while the rest do not. The average age of household heads is 47.6 , and concerning education level, most of them are educated up to high school level for approximately $89 \%$. Moreover, regarding dwelling characteristics, table 3 shows that the size of the house is varied among households with an average of $86.13 \mathrm{~m}^{2}$. Each family has about 1 to 2 types of essential electrical appliances in their home on average. Moreover, the number of rooms in their house also varied with around seven rooms on average.

Table 3: Variables included in the analysis: summary statistics

\begin{tabular}{|c|c|c|c|c|}
\hline & Average & SD & Min & Max \\
\hline \multicolumn{5}{|l|}{ Dependent Variables } \\
\hline Electricity-saving Behaviors ( $1=100 \%$ electricity-saving; $0=$ otherwise) & 0.65 & 0.48 & 0 & 1 \\
\hline \multicolumn{5}{|l|}{ Independent Variables } \\
\hline $\begin{array}{l}\text { Electricity Subsidies ( } 1=\text { subsidized household; } 0=\text { unsubsidized } \\
\text { household) }\end{array}$ & 0.80 & 0.40 & 0 & 1 \\
\hline Pro-environmental intentions & 22.82 & 2.80 & 8 & 32 \\
\hline Pro-environmental acts & 17.33 & 3.38 & 8 & 32 \\
\hline Pro-environmental gap & 5.50 & 3.70 & -21 & 22 \\
\hline Household Size & 3.98 & 1.62 & 1 & 22 \\
\hline Marital Status ( $1=$ married ; $0=$ single) & 0.85 & 0.36 & 0 & 1 \\
\hline Age & 47.57 & 12.36 & 18 & 97 \\
\hline Gender (1=Male, 1=Female) & 0.89 & 0.32 & 0 & 1 \\
\hline Education level ( $1=$ above high school; 0 =high school and below) & 0.11 & 0.31 & 0 & 1 \\
\hline Poor ( $1=$ poor 0=non poor $)$ & 0.12 & 0.33 & 0 & 1 \\
\hline Monthly Expenditure (logarithmic) & 15.09 & 0.64 & 12.23 & 18.58 \\
\hline Household location (1=urban ; 0=rural) & 0.51 & 0.50 & 0 & 1 \\
\hline Ownership Status ( $1=$ Owned; $0=$ Not Owned) & 0.81 & 0.39 & 0 & 1 \\
\hline Size of House $\left(\mathrm{m}^{2}\right)$ & 86.13 & 62.17 & 3 & 997 \\
\hline Number of Room & 6.79 & 2.28 & 1 & 26 \\
\hline Number of types of electrical appliances & 1.23 & 1.21 & 0 & 6 \\
\hline
\end{tabular}

\section{Results and Discussions}

This study runs logistic regression and calculates the marginal effect of each variable to analyze the more profound correlation between variables and electricity-saving behavior. Four models are developed to strengthen the analysis. In the first model, only the variables of electricity subsidies and environmental gaps are included in the specification to examine the result without controlling sociodemographic and dwelling characteristics. This study then includes sociodemographic and dwelling characteristics in models 2,3 , and 4 , as seen in table 4 .

Table 4: Marginal effects of estimated parameters

\begin{tabular}{|c|c|c|c|c|}
\hline Variable & Model 1 & Model 2 & Model 3 & Model 4 \\
\hline \multirow[t]{2}{*}{ Electricity Subsidies } & $-0.037 * * *$ & $-0.060 * * *$ & $-0.061 * * *$ & $-0.061 * * *$ \\
\hline & $(0.003)$ & $(0.003)$ & $(0.003)$ & $(0.003)$ \\
\hline \multirow{2}{*}{ Pro-environmental intentions } & & $-0.002 * * *$ & & \\
\hline & & $(0.000)$ & & \\
\hline \multirow[t]{2}{*}{ Pro-environmental acts } & & & $0.002^{* * *}$ & \\
\hline & & & $(0.000)$ & \\
\hline \multirow[t]{2}{*}{ Pro-environmental gap } & $-0.002 * * *$ & & & $-0.003 * * *$ \\
\hline & $(0.000)$ & & & $(0.000)$ \\
\hline \multirow[t]{2}{*}{ Household Size } & & $-0.009 * * *$ & $-0.009 * * *$ & $-0.009 * * *$ \\
\hline & & $(0.001)$ & $(0.001)$ & $(0.001)$ \\
\hline \multirow[t]{2}{*}{ Marital Status } & & -0.004 & -0.006 & -0.006 \\
\hline & & $(0.005)$ & $(0.005)$ & $(0.005)$ \\
\hline \multirow[t]{2}{*}{ Age } & & $0.002 * * *$ & $0.002 * * *$ & $0.002 * * *$ \\
\hline & & $(0.000)$ & $(0.000)$ & $(0.000)$ \\
\hline Gender & & -0.008 & -0.008 & -0.008 \\
\hline
\end{tabular}




\begin{tabular}{|c|c|c|c|}
\hline & $(0.005)$ & $(0.005)$ & $(0.005)$ \\
\hline \multirow[t]{2}{*}{ Education level } & $0.044 * * *$ & $0.042 * * *$ & $0.042 * * *$ \\
\hline & $(0.004)$ & $(0.004)$ & $(0.004)$ \\
\hline \multirow[t]{2}{*}{ Poor } & $0.009 * *$ & $0.009 * *$ & $0.009 * *$ \\
\hline & $(0.003)$ & $(0.003)$ & $(0.003)$ \\
\hline \multirow[t]{2}{*}{ Monthly Expenditure (logarithmic) } & $-0.041 * * *$ & $-0.041 * * *$ & $-0.041 * * *$ \\
\hline & $(0.002)$ & $(0.002)$ & $(0.002)$ \\
\hline \multirow[t]{2}{*}{ Household location } & $0.020 * * *$ & $0.020 * * *$ & $0.021 * * *$ \\
\hline & $(0.002)$ & $(0.002)$ & $(0.002)$ \\
\hline \multirow[t]{2}{*}{ Ownership Status } & $-0.024 * * *$ & $-0.025 * * *$ & $-0.025 * * *$ \\
\hline & $(0.003)$ & $(0.003)$ & $(0.003)$ \\
\hline \multirow[t]{2}{*}{ Size of House } & $-1.5 \times 10^{-6}$ & $-2.63 \times 10^{-6}$ & $-3.42 \times 10^{-6}$ \\
\hline & $(0.000)$ & $(0.000)$ & $(0.000)$ \\
\hline \multirow[t]{2}{*}{ Number of Room } & $-0.007 * * *$ & $-0.008 * * *$ & $-0.008 * * *$ \\
\hline & $(0.001)$ & $(0.001)$ & $(0.001)$ \\
\hline \multirow[t]{2}{*}{ Types of electrical appliances } & $-0.005 * * *$ & $-0.006 * * *$ & $-0.006 * *$ \\
\hline & $(0.001)$ & $(0.001)$ & $(0.001)$ \\
\hline
\end{tabular}

*significant at the $10 \% ;{ }^{* *}$ significant at the $5 \%$ level; ***significant at the $1 \%$ level

As can be seen in Table 4, the relationship between electricity subsidies and electricity-saving habit is significant in model 1. Moreover, the pro-environmental gap shows a meaningful and negative connection to the electricity-saving behaviors of households. In other words, the increasing gap leads to a decreasing probability of saving electricity. However, we cannot directly conclude since confounders are not included. This model could be suffered from omitted variable bias.

After controlling sociodemographic and dwelling characteristics, the results reveal that unsubsidized families tend to have electricity-saving behaviors more than subsidized ones. This consistent with the hypothesis that subsidized households have a disincentive to save electricity since they experience a lower price. Mizobuchi and Takeuchi (2013) state that electricity-saving behaviors are not only about public goods such as being pro-environmental but also of private goods, such as saving money. Therefore, by doing electricity-saving, unsubsidized households can save or allocate funds for other needs. The results also show that electricity subsidies have the highest marginal effect on the behaviors, which means that financial factors become the most electricity-saving drivers compared to the other elements. This finding matches with Jia, Xu, Fan, \& Ji, (2018) which explain that financial incentives are the most crucial determinant encouraging the public to apply energy-saving measures in daily life.

For the household environmental aspect, this study involves the variable of pro-environmental intentions, acts, and the gap in the separated model. In model 2, the regression result shows that higher pro-environmental intentions do not always make individuals save electricity. Unlike pro-environmental intentions, the pro-environmental acts variable shows a different relationship with electricity-saving behaviors. Families with higher pro-environmental intentions are not necessarily likely to save electricity, while households with pro-environmental routines are likely to do so.

The contradictive result between pro-environmental intentions and acts become interesting findings. Therefore, this study further examines the environmental aspect by observing the intentionbehaviors gap. Model 4 shows that the household pro-environmental gap is negatively significant in correlating electricity-saving behaviors. It means that if families have more pro-environmental intentions but do not fully implement them as daily routines, they are less likely to have the electricity-saving behaviors. This finding is interesting since the intention-behaviors gap is a phenomenon that is recognized by many researchers. Frederiks, Stenner, and Hobman (2015) realize that even if people receive sufficient knowledge of how to save energy and proclaim the desire to perform it, many consumers still fail to implement as real acts. . Therefore, this study believes that to intensify electricity-saving routines, the households' pro-environmental gap should be minimized.

There are some possibilities for why intention-behavior gaps exist. Blake (1999) explains that individuality, responsibility, and practicality become the barrier to do pro-environmental actions. Practicality constraints such as lack of time, lack of money, and lack of information; for example, could encourage people not to act environmentally friendly regardless of their intentions. However, most researchers realize that the intention-behavior gap is a complex issue; therefore, it is recommended to observe this issue in a future study.

As expected before, financial incentives play a crucial role in influencing consumers' behaviors. The empirical results reveal that an electricity subsidies policy for particular households reduces the electricity-saving habit. This reaction makes sense since subsidized homes receive lower tariffs compared to unsubsidized ones. Moreover, an interesting finding is obtained in terms of non-financial considerations, where families with higher pro-environmental intentions are not necessarily likely to save 
electricity due to the existence of intention-behavior gaps. The increasing gap leads to diminishing electricity-saving practices of households. This study demonstrates that the intention-behavior gaps also exist in pro-environmental terms, and interestingly correlates with electricity-saving habit. Besides, this finding significantly contributes to research on the energy-saving issue since there are not many researchers who specifically address the pro-environmental gaps in electricity-saving behaviors.

Further policy measures could be implemented with the factors examined above taken into account. Firstly, subsidies reform should be carried out gradually. The study, which is also supported by previous research, shows that financial aspects mostly encourage consumers to change their behaviors in consuming energy. Furthermore, policymakers should not only focus on increasing knowledge and awareness concerning pro-environmental behaviors but also try to make sure people will manifest into real acts. The government can take advantage of technological developments to solve this problem. One way is to build a comprehensive system to monitor the behaviors of the consumers. This kind of system enables consumers to measure their behaviors when consuming electricity. Indeed, policymakers should first pay attention to factors that could influence the inconsistency between the intentions and acts such as social norms, cost and benefit, and previous experience with the environmental problem, and this important for them to examine in further research.

\section{Conclusions}

The relationship between electricity subsidies and pro-environmental factors of household in electricity-saving become the main focus of this research. It is hypothesized that electricity subsidies correlate with electricity-saving habit since those who receive subsidies pay the lower price. Besides, the discrepancy between pro-environmental intentions and acts may influence the behaviors of the households. Previous studies reveal that sociodemographic, dwellings, environmental aspects, and government policies affect the behaviors of families in consuming electricity. Then, to analyze the hypotheses, logit regression is applied by using Indonesian household microdata.

This study noted that electricity subsidies are the primary driver to discourage households from doing do electricity-saving routines. After controlling sociodemographic and dwelling characteristics, subsidized homes are less likely to save electricity compared to unsubsidized ones. Since the subsidized families experience a lower price, they have a disincentive to save the electricity in their home, and this is in line with the hypotheses. On the other hand, unsubsidized families can save or allocate money for different needs by applying electricity-saving. Therefore, the government should conduct subsidies reform gradually. The expected response of this reform is a behavioral change in consuming electricity, such as reducing air conditioning usage, turning off electrical appliances when unused, and shifting to use more energy-efficient appliances. Furthermore, these behavioral changes are expected to make a positive contribution to reducing $\mathrm{CO}_{2}$ emissions to support SGDs. However, since there are a few substitutes for electricity sources in Indonesia, a gradual reduction in electricity subsidies is recommended instead of eliminating the subsidies.

An interesting finding is obtained when examining the correlation of the pro-environmental gap on electricity-saving routines. The pro-environmental gap is negative and significant, associating the electricity-saving behaviors of households. It means that increasing differences between intention and real acts leads to decreasing the probability of families saving electricity. Moreover, the intentionbehaviors gap shows that what individuals proclaim and what they do are two different things. This discrepancy explains why education programs and government campaigns about pro-environmental habits and SGDs often fail to induce a behavioral change of the consumers. Consequently, to reduce the pro-environmental gap, policymakers should not only focus on increasing pro-environmental knowledge and awareness but also try to make sure that the people fully translate the intentions as habits. The government could develop a comprehensive system as a new approach to monitor the behaviors of the consumers. However, policymakers should firstly examine factors that affect the inconsistency between the intentions and acts.

Overall, by paying attention to financial incentives and the gap between intentions and actual behavior in society, the policymakers are expected to be able to implement appropriate policies to support electricity-saving behaviors that have a direct impact on the achievement of the SDGs as well. Moreover, the current pandemic condition also allows changes in household behavior in consuming electricity. Therefore, future research could focus on observing determinants influencing the proenvironmental gaps such as social norms, sociodemographic, and cost-benefit. Besides, the relationship 
between the pandemic situation and the behavior of the household could be also an interesting study in the future.

\section{Acknowledgments}

My acknowledgment goes to, the head of MPKP University of Indonesia, Rikkyo University, Bappenas, The Ministry of Energy and Mineral Resources, colleagues, and friends for the opportunity, guidance, and support during the writing of this research paper.

\section{References}

Barr, S., Gilg, A. W., \& Ford, N. (2005). The household energy gap: examining the divide between habitualand purchase-related conservation behaviors. Energy Policy, 33(11), 1425-1444. https://doi.org/10.1016/J.ENPOL.2003.12.016

Blake, J. (1999). Overcoming the "value-action gap" in environmental policy: Tensions between national policy and local experience. Local Environment, 4(3), 257-278. https://doi.org/10.1080/13549839908725599

Burke, P. J., \& Kurniawati, S. (2018). Electricity subsidy reform in Indonesia: Demand-side effects on electricity use. Energy Policy, 116(June 2017), 410-421. https://doi.org/10.1016/j.enpol.2018.02.018

Ding, Z., Wang, G., Liu, Z., \& Long, R. (2017). Research on differences in the factors influencing the energysaving behavior of urban and rural residents in China-A case study of Jiangsu Province. Energy Policy, 100(September 2016), 252-259. https://doi.org/10.1016/j.enpol.2016.10.013

Erell, E., Portnov, B. A., \& Assif, M. (2018). Modifying behaviour to save energy at home is harder than we think.... Energy and Buildings, 179, 384-398. https://doi.org/10.1016/j.enbuild.2018.09.010

Fiorillo, D., \& Sapio, A. (2019). Energy saving in Italy in the late 1990s: Which role for non-monetary motivations? Ecological Economics, 165(August 2018), 106386. https://doi.org/10.1016/j.ecolecon.2019.106386

Frederiks, E. R., Stenner, K., \& Hobman, E. V. (2015). Household energy use : Applying behavioural economics to understand consumer decision-making and behaviour. Renewable and Sustainable Energy Reviews, 41, 1385-1394. https://doi.org/10.1016/j.rser.2014.09.026

Hong, J., She, Y., Wang, S., \& Dora, M. (2019). Impact of psychological factors on energy-saving behavior : Moderating role of government subsidy policy. Journal of Cleaner Production, 232, 154-162. https://doi.org/10.1016/j.jclepro.2019.05.321

Hori, S., Kondo, K., Nogata, D., \& Ben, H. (2013). The determinants of household energy-saving behavior : Survey and comparison in five major Asian cities. Energy Policy, 52, 354-362. https://doi.org/10.1016/j.enpol.2012.09.043

IESR. (2019). Brown to Green: Transisi G20 Menuju Ekonomi Rendah Karbon, 53(9), 1689-1699.

International Energy Agency. (2017). Energy Efficiency 2017.

J. Walsh, M. (1989). Energy tax credits and housing improvement. Energy Economics (Vol. 11). https://doi.org/10.1016/0140-9883(89)90043-1

Jamaludin. (2020). Understanding Perception and Interpretation of Malaysian University Students on Renewable Energy. Aims Energy, 8, 6.

Jia, J. J., Xu, J. H., Fan, Y., \& Ji, Q. (2018). Willingness to accept energy-saving measures and adoption barriers in the residential sector: An empirical analysis in Beijing, China. Renewable and Sustainable Energy Reviews, 95(July), 56-73. https://doi.org/10.1016/j.rser.2018.07.015

Liu, C., \& Lin, B. (2020). Is increasing-block electricity pricing effectively carried out in China ? A case study in Shanghai and Shenzhen. Energy Policy, 138(April 2017), 111278. https://doi.org/10.1016/j.enpol.2020.111278

Ministry of Energy and Mineral Resources Republic of Indonesia. (2018). Handbook of Energy and Economic Statistics of Indonesia. Jakarta. Retrieved from https://www.esdm.go.id/assets/media/content/content-handbook-of-energy-and-economicstatistics-of-indonesia.pdf

Mizobuchi, K., \& Takeuchi, K. (2013). The influences of financial and non-financial factors on energy-saving behaviour: A field experiment in Japan. Energy Policy, 63, 775-787. https://doi.org/10.1016/j.enpol.2013.08.064

Nakano, R., Zusman, E., Nugroho, S., Kaswanto, R. L., Arifin, N., Munandar, A., ... Fujita, T. (2018). 
Determinants of energy savings in Indonesia: The case of LED lighting in Bogor. Sustainable Cities and Society, 42(May), 184-193. https://doi.org/10.1016/j.scs.2018.06.025

Nusrat Afroz, \& Zul Ilham. (2020). Assessment of Knowledge, Attitude and Practice of University Students towards Sustainable Development Goals (SDGs). The Journal of Indonesia Sustainable Development Planning, 1(1), 31-44. https://doi.org/10.46456/jisdep.v1i1.12

Ohler, A. M., \& Billger, S. M. (2014). Does environmental concern change the tragedy of the commons? Factors affecting energy saving behaviors and electricity usage. Ecological Economics, 107, 1-12. https://doi.org/10.1016/j.ecolecon.2014.07.031

Oikonomou, V., Becchis, F., Steg, L., \& Russolillo, D. (2009). Energy saving and energy efficiency concepts for policy making. Energy Policy, 37(11), 4787-4796. https://doi.org/10.1016/J.ENPOL.2009.06.035

Ritchie, J. R. B., Mcdougall, G. H. G., Claxton, J. D., Mcdougall, G. H. G., \& Claxton, J. D. (1981). Complexities of Household Energy Consumption and Conservation Linked references are available on JSTOR for this article : Complexities of Household Energy Consumption and Conservation. Journal of Consumer Research, 8(3), 233-242.

$\mathrm{Ru}, \mathrm{X} .$, Wang, S., \& Yan, S. (2018). Exploring the effects of normative factors and perceived behavioral control on individual's energy-saving intention: An empirical study in eastern China. Resources, Conservation and Recycling, 134(96), 91-99. https://doi.org/10.1016/j.resconrec.2018.03.001

Sardianou, E. (2007). Estimating energy conservation patterns of Greek households. Energy Policy, 35(February 2003), 3778-3791. https://doi.org/10.1016/j.enpol.2007.01.020

Schleich, J., Mills, B., \& Dütschke, E. (2014). A brighter future? Quantifying the rebound effect in energy efficient lighting. Energy Policy, 72, 35-42. https://doi.org/10.1016/j.enpol.2014.04.028

Sheeran, P., \& Webb, T. L. (2016). The Intention-Behavior Gap. Social and Personality Psychology Compass, 10(9), 503-518. https://doi.org/10.1111/spc3.12265

Trotta, G. (2018). Factors affecting energy-saving behaviours and energy efficiency investments in British households, 114(December 2017), 529-539. https://doi.org/10.1016/j.enpol.2017.12.042

Uidhir, T. Mac, Rogan, F., Collins, M., Curtis, J., \& Gallachóir, B. P. Ó. (2020). Improving energy savings from a residential retrofit policy: A new model to inform better retrofit decisions. Energy and Buildings, 209. https://doi.org/10.1016/j.enbuild.2019.109656

Umit, R., Poortinga, W., Jokinen, P., \& Pohjolainen, P. (2019). The role of income in energy efficiency and curtailment behaviours: Findings from 22 European countries. Energy Research and Social Science, 53(August 2018), 206-214. https://doi.org/10.1016/j.erss.2019.02.025

Vogiatzi, C., Gemenetzi, G., Massou, L., Poulopoulos, S., Papaefthimiou, S., \& Zervas, E. (2018). Energy use and saving in residential sector and occupant behavior: A case study in Athens. Energy and Buildings, 181(2018), 1-9. https://doi.org/10.1016/j.enbuild.2018.09.039

Wang, B., Wang, X., Guo, D., Zhang, B., \& Wang, Z. (2018). Analysis of factors influencing residents' habitual energy-saving behaviour based on NAM and TPB models: Egoism or altruism? Energy Policy, 116(January), 68-77. https://doi.org/10.1016/j.enpol.2018.01.055

Wang, S., Lin, S., \& Li, J. (2018). Exploring the eff ects of non-cognitive and emotional factors on household electricity saving behavior. Energy Policy, 115(32), 171-180. https://doi.org/10.1016/j.enpol.2018.01.012

Wang, Z., Zhang, B., Yin, J., \& Zhang, Y. (2011). Determinants and policy implications for household electricity-saving behaviour: Evidence from Beijing, China. Energy Policy, 39(6), 3550-3557. https://doi.org/10.1016/J.ENPOL.2011.03.055

Webb, D., Soutar, G. N., Mazzarol, T., \& Saldaris, P. (2013). Self-determination theory and consumer behavioural change: Evidence fromahousehold energy-saving behaviour study. Journal of Environmental Psychology, 35, 59-66. https://doi.org/10.1016/j.jenvp.2013.04.003

Yang, S., Zhang, Y., \& Zhao, D. (2016). Who exhibits more energy-saving behavior in direct and indirect ways in china? The role of psychological factors and socio-demographics. Energy Policy, 93, 196205. https://doi.org/10.1016/j.enpol.2016.02.018

Yue, T., Long, R., \& Chen, H. (2013). Factors in fl uencing energy-saving behavior of urban households in Jiangsu Province. Energy Policy, 62, 665-675. https://doi.org/10.1016/j.enpol.2013.07.051

Zhang, C., Yu, B., Wang, J., \& Wei, Y. (2018). Impact factors of household energy-saving behavior : An empirical study of Shandong Province in China. Journal of Cleaner Production, 185, 285-298. https://doi.org/10.1016/j.jclepro.2018.02.303

Zhao, X., Cheng, H., Zhao, H., Jiang, L., \& Xue, B. (2019). Survey on the households' energy-saving behaviors and influencing factors in the rural loess hilly region of China. Journal of Cleaner Production, 230, 
547-556. https://doi.org/10.1016/j.jclepro.2019.04.385 